\title{
Epidemiology of Hepatitis E Virus in an Urban Community in Dhaka City
}

\author{
${ }^{1}$ Salimur Rahman, ${ }^{2}$ Mamun-Al-Mahtab, ${ }^{3}$ Munira Jahan, ${ }^{4}$ Shahina Tabassum, ${ }^{5}$ Sheikh Mohammad Fazle Akbar
}

\begin{abstract}
Introduction: Hepatitis E virus (HEV) is endemic in Bangladesh and sporadic and epidemic outbreaks of acute hepatitis $\mathrm{E}$ occur in this country almost regularly. Although the real magnitude of HEV prevalence has not been documented in Bangladesh, HEV infections and HEV-related acute hepatitis of Bangladeshi origin have been reported from different parts of the world.
\end{abstract}

Methods: The study was conducted in Mirpur area of Dhaka city, which is a major residential area of the capital of Bangladesh. Three hundred adults were randomly included in the study. None had any history of jaundice or complains of liver diseases.

Results: The study revealed $30 \%$ prevalence of HEV in this population. The prevalence increased with age, but there was no gender difference.

Conclusion: HEV is a highly prevalent disease in Bangladesh as elsewhere in the developing world. Since there is no specific treatment for HEV, improvement of personal hygiene and ensuring supply of safe food and drinking water remain most important approach to sustain the virus.

Keywords: Hepatitis E, Prevalence, Urban population.

How to cite this article: Rahman S, Mahtab MA, Jahan M, Tabassum S, Akbar SMF. Epidemiology of Hepatitis E Virus in an Urban Community in Dhaka City. Euroasian J Hepato-Gastroenterol 2014; 4(1):4-6.

Source of support: Nil

Conflict of interest: None declared

\section{INTRODUCTION}

Hepatitis E virus (HEV) is a spherical, nonenveloped, singlestranded RNA virus ${ }^{1}$ having 5 genotypes designated from I-V. Of these, genotype I has been reported from Asia and Africa, genotype II from United States, genotype III from Mexico, genotype IV from China and genotype V from Europe. $^{2-4}$

$\mathrm{HEV}$ is excreted in feces and transmission is predominantly by fecal-oral route, usually through contaminated water. ${ }^{5}$ Most HEV outbreaks have been reported during rainy seasons and after floods. ${ }^{6}$ There is also evidence of blood-borne transmission of HEV and zoonotic transmission of HEV in advanced countries. ${ }^{7-9}$ In between outbreaks, subclinical HEV-infections in humans and/or animals act as reservoir for the virus. ${ }^{10}$
Hepatitis E virus is endemic in Bangladesh and sporadic and epidemic outbreaks of acute hepatitis E occur in this country almost regularly. Some hospital-based studies have also shown that HEV is main etiological agent of acute hepatitis, ${ }^{11}$ fulminant hepatitis, ${ }^{12,13}$ and acute on chronic liver failure $^{14}$ at Bangladesh. However, little has been explored about prevalence of HEV among general population. One study by Labrique et $\mathrm{al}{ }^{15}$ exposed that about $23 \%$ of apparently healthy population of rural Bangladesh were seropositive for HEV. However, there is a paucity of information about sero-prevalence of HEV among urban population of Bangladesh. This is an important issue because the route of transmission of HEV may be different between rural and urban populations. In addition, most of the epidemics of HEV have been reported from urban areas. The study was accomplished at Dhaka, the capital of Bangladesh.

\footnotetext{
1,2Department of Hepatology, Bangabandhu Sheikh Mujib Medical University, Dhaka, Bangladesh

${ }^{3,4}$ Department of Virology, Bangabandhu Sheikh Mujib Medical University, Dhaka, Bangladesh

${ }^{5}$ Department of Medical Sciences, Toshiba General Hospital, Tokyo, Japan
}

Address reprint requests to: Mamun-Al-Mahtab, Associate Professor, Department of Hepatology, Bangabandhu Sheikh Mujib Medical University, Dhaka, Bangladesh, e-mail: shwapnil@agni.com 
Epidemiology of Hepatitis E Virus in an Urban Community in Dhaka City

\begin{tabular}{|c|c|c|c|c|c|}
\hline Age (years) & No. & Male & Female & $\begin{array}{l}\text { Anti-HEV IgG } \\
\text { positive }\end{array}$ & Percentage (\%) \\
\hline $18-30$ & 87 & $39(42.8 \%)$ & $48(57.2 \%)$ & $\begin{array}{l}24(27.6 \%) \\
(M: F=9: 15)\end{array}$ & $\mathrm{M}: \mathrm{F}=37.5: 62.5$ \\
\hline $31-40$ & 60 & $27(45 \%)$ & $33(55 \%)$ & $\begin{array}{l}24(40 \%) \\
(M: F=9: 15)\end{array}$ & $\mathrm{M}: \mathrm{F}=37.5: 62.5$ \\
\hline $41-50$ & 84 & $48(57.1 \%)$ & $36(42.9 \%)$ & $\begin{array}{l}18(21.4 \%) \\
(M: F=15: 3)\end{array}$ & $M: F=83.3: 16.7$ \\
\hline $51-60$ & 42 & $24(57.1 \%)$ & $18(42.9 \%)$ & $\begin{array}{l}15(35.7 \%) \\
(\mathrm{M}: \mathrm{F}=12: 3)\end{array}$ & $M: F=80: 20$ \\
\hline$>60$ & 27 & $12(44.4 \%)$ & $15(55.6 \%)$ & $\begin{array}{l}09(52.9 \%) \\
(\mathrm{M}: \mathrm{F}=3: 6)\end{array}$ & $M: F=33.3: 66.7$ \\
\hline
\end{tabular}

HEV: Hepatitis E virus, IgG: Immunoglobulin

\section{METHODS}

The study was conducted in Mirpur area of Dhaka city, which is a major residential area of the capital of Bangladesh. Ethical approval of the study was obtained from the Ethical Committee at Viral Hepatitis Foundation of Bangladesh. In this pilot study, a total of 300 adults, aged between 18 and 67 years, were enrolled (Table 1). One participant was randomly selected from every one in ten households of the area. The first 300 adults with an equal distribution of male and female were included. Informed written consent was obtained from each participant. Five milliliter of venous blood was obtained from each person with full aseptic precautions. Sera were separated immediately to avoid hemolysis, appropriately labeled and stored at $-20^{\circ} \mathrm{C}$ until assessment. Stored sera were subsequently tested for anti-HEV immunoglobulin $\mathrm{G}$ (IgG) by enzyme-linked immunosorbent assay (ELISA) (Institute of Immunology Co. Ltd., Tokyo, Japan).

\section{RESULTS}

The age of subjects ranged from 18 to 67 years. Of them, 150 were males and rest 150 females. None had any history of jaundice or complains of liver diseases. Also, there was no subjective symptom of liver diseases in any patient. Ninety $(30 \%)$ were tested positive for anti-HEV IgG. The prevalence was lowest among 18 to 30 years age group where it was $27.6 \%$, rising more or less steadily with age peaking at $52.9 \%$ among those above 60 years of age. The only exception is the age group 41 to 50 years, where the prevalence declines to $21.4 \%$.

Both sexes are affected equally and no sex predominance was noted. The figures vary between men and women in different age groups. For example, the male prevalence is almost 4 times higher than females in those between 41 and 60 years of age, but in case of females over 60 years, the prevalence is almost 3 times higher than males. And the prevalence of anti-HEV IgG is roughly double in females than that in males among the 18 to 40 years age group.

\section{DISCUSSION}

Although HEV has been shown to be the main etiological agent for acute hepatitis, ${ }^{11}$ fulminant hepatitis ${ }^{12,13}$ and acute on chronic liver failure, ${ }^{14}$ prevalence of HEV has seldom been studied in Bangladesh. This study is the second that assessed the prevalence of HEV among apparently healthy individuals. Labrique et $\mathrm{al}^{15}$ have shown that about $22 \%$ of rural Bangladeshi was expressing $\mathrm{IgG}$ type antibody to $\mathrm{HEV}$. We have shown that $27 \%$ of urban Bangladeshi showed evidence of past HEV infection. Taken together, it can be postulated that HEV is highly endemic in both rural and urban population of Bangladesh, although the source of water and means of disposal of sewerage show marked differences among rural and urban areas of Bangladesh.

Although the real magnitude of HEV prevalence has not been documented by epidemiological studies, HEV infections and HEV-related acute hepatitis of Bangladeshi origin have been reported from different parts of the world. The first report of HEV-related acute hepatitis E has been among the inhabitants. The Netherlands who traveled to Bangladesh in early 1990s. ${ }^{16}$ Subsequently, acute hepatitis E has been reported from nationals of Spain, Japan and Italy ${ }^{17-20}$ who traveled to Bangladesh. In addition, acute hepatitis $\mathrm{E}$ has also been recorded among United Nation Peace keepers of Bangladeshi origin at Haiti. ${ }^{21,22}$

The present study and that of Labrique et $\mathrm{al}^{15}$ have provided some clue regarding $\mathrm{HEV}$ infection among people traveling to Bangladesh. Usually, travelers try to take care of different public health measures during their travel. However, as one of every 3 to 4 apparently healthy Bangladeshi is infected with $\mathrm{HEV}$, acquisition of $\mathrm{HEV}$ is a common factor for travelers coming to Bangladesh.

\section{ACKNOWLEDGMENT}

The study was supported by financial contribution of Mrs Sayeda Rahman, Dhaka, Bangladesh. 


\section{REFERENCES}

1. Péron JM, Mansuy JM, Izopet J, Vinel JP. (Hepatitis E virus: an emerging disease). Sante 2006 Oct-Dec;16(4):239-243.

2. Tsarev SA, Binn LN, Gomatos PJ, Arthur RR, Monier MK, van Cuyck-Gandre H, Longer CF, Innis BL. Phylogenetic analysis of hepatitis E virus isolates from Egypt. J Med Virol 1999 Jan;57(1):68-74.

3. Wang Y, Ling R, Erker JC, Zhang H, Li H, Desai S, Mushahwar IK, Harrison TJ. A divergent genotype of hepatitis E virus in Chinese patients with acute hepatitis. J Gen Virol 1999 Jan;80(Pt 1):| 169-177.

4. Schlauder GG, Desai SM, Zanetti AR, Tassopoulos NC, Mushahwar IK. Novel hepatitis E virus (HEV) isolates from Europe: evidence for additional genotypes of HEV. J Med Virol 1999 Mar;57(3):243-251.

5. Balayan MS, Andjaparidze AG, Savinskaya SS, Ketiladze ES, Braginsky DM, Savinov AP, Poleschuk VF.Balayan MS, Andjaparidze AG, Savinskaya SS, et al. Evidence for a virus in non-A, non-B hepatitis transmitted via the fecal-oral route. Intervirology 1983;20(1):23-31.

6. Uchida T. Hepatitis E: review. Gastroenterol Jpn. 1992 Oct;27(5):687-696.

7. Ayoola EA, Want MA, Gadour MO, Al-Hazmi MH, Hamza MK. Hepatitis E virus infection in haemodialysis patients: a case-control study in Saudi Arabia. J Med Virol 2002 Mar;66(3):329-334.

8. Okamoto H, Takahashi M, Nishizawa T, Fukai K, Muramatsu U, Yoshikawa A. Analysis of the complete genome of indigenous swine hepatitis E virus isolated in Japan. Biochem Biophys Res Commun 2001 Dec 21;289(5):929-936.

9. Hsieh SY, Meng XJ, Wu YH, Liu ST, Tam AW, Lin DY, Liaw YF. Identity of a novel swine hepatitis E virus in Taiwan forming a monophyletic group with Taiwan isolates of human hepatitis E virus. J Clin Microbiol 1999 Dec;37(12):3828-3834.

10. Meng XJ, Purcell RH, Halbur PG, Lehman JR, Webb DM, Tsareva TS, Haynes JS, Thacker BJ, Emerson SU. A novel virus in swine is closely related to the human hepatitis E virus. Proc Natl Acad Sci USA 1997 Sep;94(18):9860-9865.

11. Mamun-Al-Mahtab, Rahman S, Khan M, Karim F. HEV infection as an aetiologic factor for acute hepatitis: experience from a tertiary hospital in Bangladesh. J Health Popul Nutr 2009 Feb;27(1):14-19.
12. Sheikh A1, Sugitani M, Kinukawa N, Moriyama M, Arakawa Y, Komiyama K, Li TC, Takeda N, Ishaque SM, Hasan M, Suzuki $\mathrm{K}$. Hepatitis e virus infection in fulminant hepatitis patients and an apparently healthy population in Bangladesh. Am J Trop Med Hyg 2002 Jun;66(6):721-724.

13. Alam S, Azam G, Mustafa G, Azad AK, Haque I, Gani S, Ahmad N, Alam K, Khan M. Natural course of fulminant hepatic failure: the scenario in Bangladesh and the differences from the west. Saudi J Gastroenterol 2009 Oct-Dec;15(4):229-233.

14. Mahtab MA, Rahman S, Khan M, Karim MF. Hepatitis E virus is a leading cause of acute-on-chronic liver disease: experience from a tertiary centre in Bangladesh. Hepatobiliary Pancreat Dis Int $2009 \mathrm{Feb} ; 8(1): 50-52$.

15. Labrique AB, Zaman K, Hossain Z, Saha P, Yunus M, Hossain A, Ticehurst J, Nelson KE. Population seroprevalence of hepatitis E virus antibodies in rural Bangladesh.Am J Trop Med Hyg 2009 Nov;81(5):875-881.

16. Zaaijer HL, Kok M, Lelie PN, Timmerman RJ, Chau K, van der Pal HJ. Hepatitis E in The Netherlands: imported and endemic. Lancet 1993 Mar;27;341(8848):826.

17. Sanayama Y, Ishiwada N, Fukasawa C, Kanazawa M, Tamano Y, Yano K, Kohno Y. A pediatric patient with acute hepatitis E in Japan. J Infect Chemother 2008 Oct;14(5):374-376.

18. Fogeda M, Avellón A, Cilla CG, Echevarría JM. Imported and autochthonous hepatitis E virus strains in Spain. J Med Virol 2009 Oct;81(10):1743-1749.

19. La Rosa G, Muscillo M, Vennarucci VS, Garbuglia AR, La Scala P, Capobianchi MR. Hepatitis E virus in Italy: molecular analysis of travel-related and autochthonous cases. J Gen Virol 2011 Jul;92(Pt 7):1617-1626.

20. Romanò L, Paladini S, Tagliacarne C, Canuti M, Bianchi S, Zanetti AR. Hepatitis $\mathrm{E}$ in Italy: a long-term prospective study. J Hepatol 2011 Jan;54(1):34-40.

21. Drabick JJ, Gambel JM, Gouvea VS, Caudill JD, Sun W, Hoke $\mathrm{CH} \mathrm{Jr}$, Innis BL. A cluster of acute hepatitis E infection in United Nations Bangladeshi peacekeepers in Haiti. Am J Trop Med Hyg 1997 Oct;57(4):449-454.

22. Gambel JM, Drabick JJ, Seriwatana J, Innis BL. Seroprevalence of hepatitis E virus among United Nations Mission in Haiti (UNMIH) peacekeepers, 1995. Am J Trop Med Hyg 1998 Jun; 58(6):731-736. 